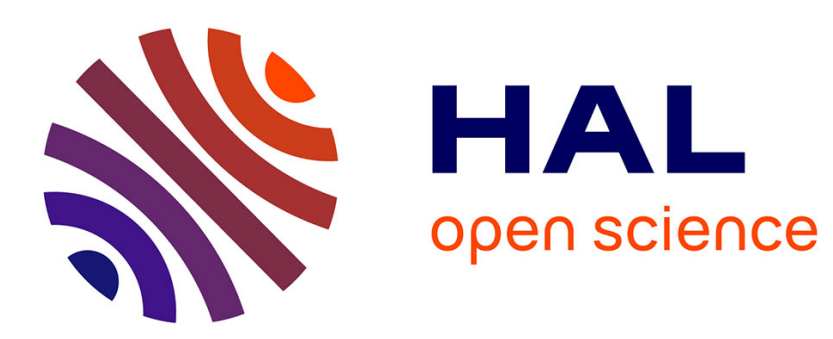

\title{
From here because from abroad? Migrants and Grassroots Memorials in Paris in this Aftermath of November 13, 2015
}

Sarah Gensburger, Gérôme Truc

\section{- To cite this version:}

Sarah Gensburger, Gérôme Truc. From here because from abroad? Migrants and Grassroots Memorials in Paris in this Aftermath of November 13, 2015. Sabine Marschall. Public Memory in the Context of Transnational Migration and Displacement, Palgrave Macmillan, pp.219-242, 2020, Palgrave Macmillan Memory Studies, 978-3-030-41331-6. 10.1007/978-3-030-41329-3_8. halshs-03063755

\section{HAL Id: halshs-03063755 \\ https://shs.hal.science/halshs-03063755}

Submitted on 1 Sep 2021

HAL is a multi-disciplinary open access archive for the deposit and dissemination of scientific research documents, whether they are published or not. The documents may come from teaching and research institutions in France or abroad, or from public or private research centers.
L'archive ouverte pluridisciplinaire HAL, est destinée au dépôt et à la diffusion de documents scientifiques de niveau recherche, publiés ou non, émanant des établissements d'enseignement et de recherche français ou étrangers, des laboratoires publics ou privés. 


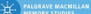
memonr sivo es

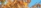

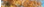

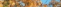

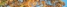

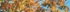

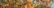

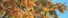

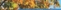

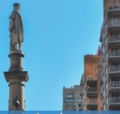

* Public Memory in the

6. Context of Transnational

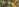

Migration and
Displacement - Migrants and M

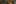
nxic

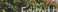

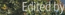

S Sibine Mats thall

$\left.a^{2}+x^{2}+2\right)$

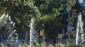

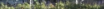

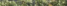

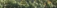
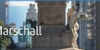

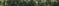

Vonuments
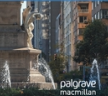

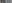

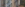

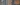

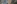

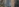




\section{Chapter 8}

\section{From Here because from Abroad? Migrants and Grassroots Memorials in Paris in the Aftermath of 13 November 2015}

\section{Sarah Gensburger and Gérôme Truc}

\section{Introduction: Making migrants visible at grassroots memorials}

On the night of 13 November 2015, three gunmen rushed inside the Bataclan, a concert hall located on Boulevard Voltaire in the $11^{\text {th }}$ arrondissement of Paris, only one block away from Place de la République. They opened fire on the crowd. On this same night, other gunmen shot people in several other cafés and restaurants around the same area, as well as in the nearby $10^{\text {th }}$ arrondissement, leaving a total of 130 people dead and almost 500 wounded. Immediately, the affected neighbourhoods became a stage for the memorialization, tributes and homages to the victims.

On 9 January 2016, one of us was conducting fieldwork, observing the areas around the Bataclan which had turned into a huge memorial. While there, we met a man wearing a yellow baseball cap, carrying two large bags. He was from Mali and he talked to us informally, in broken French ${ }^{1}$. He was used to walking this way, he said; he had come to look for the photograph of a man who volunteered in distributing free food 'for the hungry' at the Place de la République (a site for the distribution of free meals for a long time), and who had always been very nice to him. He had not seen the man since 13 November and had been told that he had been killed in the Bataclan. He didn't know his name but had wanted to come and pay his respects to him. For several months, well before the attacks, this man had passed along the Boulevard Voltaire and the Bataclan every day to go to the Place de la République, where hot lunches were served to the needy. Now, every time he passes, he looks to see if the man's photograph has been added. He was very upset when he talked about it, just as he was when he described his own experiences of the night of 13 November, a night without sleep, talking endlessly with his fellows on the street. This witness lives on the street and is an undocumented migrant. Yet he is no less a resident of the neighbourhood and was clearly touched by the events. It is highly unlikely, however, that his experiences will be preserved among the testimonies being collected in the oral history programmes which, as it was the case in New York after 9/11, have been flourishing in France since the end of 2015.

\footnotetext{
1 Unlike what happens in the English-speaking world, social science research in France does not have to be approved by a university ethics committee to proceed and no formal agreement is needed to reproduce interviews quotations. However, French researchers have, of course, also some ethical principles. In the present case, firstly, we made sure that the anonymity of anyone we spoke with was protected. Secondly, we tried hard to find writing style that was as free as possible from any moral or judgmental perspectives, in order to really give a voice to everyone we interviewed, encountered, interacted with, or simply observed.
} 
During the past two decades, many researchers have paid attention to the 'spontaneous shrines' or 'temporary memorials' which tend to flourish in the streets after terrorist attacks or other traumatic events (Santino 2006; Doss 2008; Magry and SánchezCarretero 2011). These are most often now conceived as parts of a 'grassroots memorialization' process, understood as

the process by which groups of people, imagined communities, or specific individuals bring grievances into action by creating an improvised and temporary memorial with the aim of changing or ameliorating a particular situation (Margry and Sánchez-Carretero 2011, p.2).

As it appears these singular types of immediate commemorative monuments, which are a prominent form of social responses to terrorist attacks in western societies (Truc 2018), systematically articulate local, national and cosmopolitan expressions of grief and concern (Guisan 2009).

However, so far, and strangely enough, the migrants' relationships to these memorials have been relatively neglected by those who study the social reactions to terrorist attacks, except a few exceptions (Chulilla 2005; Yocom 2006; Doving 2018; Lödén 2018; Sanchez-Carretero 2019). They have been of no more interest to the broader literature on collective and public mourning (Elliott 1999; Keard and Steinberg 1999; Walter 1999; Walter 2001; Ben Amos 2000; Fureix 2009). While some migrants are socially invisible, as in the case of the one mentioned above, this lack of research contributes to the double disappearance (Edkins 2011) of migrants as participants in collective mourning and commemoration after terrorist attacks. In the Paris case, paying attention to these social actors is crucial and urgent since in September 2018, the French president announced the creation of a national memorial museum for terror victims, in which, with no doubt, this popular expression at the grassroots memorial will play a central role (Gensburger 2019). Giving voice to the migrants' practices at and views of these memorials is part of a larger ongoing reflection on the best way to 'create the conditions for an inclusive or exclusive memorial site' after terrorist attacks (Délano and Niemass 2014, p.403). It might also enable us to better grasp how Muslim people living in France reacted to the 2015 Islamist attacks, beyond public discourses criticizing their so-called 'silence' in the immediate aftermath of the event and demanding that they dissociate themselves from the perpetrators (Geisser, MarongiuPerria and Smail 2017).

Beyond the opening encounter of this chapter, migrants, in legal or illegal situations, in transit or settled in France, appeared at several occasions in our fieldwork while studying social responses to Paris attacks and their memorialization. The current text takes stock of three groups of data. First, being both a sociologist of memory and an inhabitant of the Bataclan neighbourhood, one of us conducted daily ethnographic fieldwork for a period of one year in this new memory landscape, taking observation notes, conducting interviews and listening to ordinary conversations (Gensburger 2018 and 2019). ${ }^{2}$ Secondly, since the end of this in-depth research period and together with a group of colleagues and students, we have conducted additional research on site for the annual anniversaries of the attacks, in November 2016, 2017 and 2018 (Antichan, Gensburger and Griveaud 2017). Indeed, and beyond the spontaneous grassroots

\footnotetext{
${ }^{2}$ Thanks to Sylvain Antichan and Brian Chauvel for their participation in some of these fieldwork observations.
} 
memorials, several commemorative plaques have been inaugurated in 2016 for the first anniversary of the events. They offer a starting point for conducting fieldwork on commemorative practices, as has been done in the case of previous terrorist attacks in other European centres (Tota 2003, 2004, 2005; Truc 2011, 2012; Allen and Brown 2016). Finally, starting in December 2015, the Paris Archives progressively collected the tributes left at the grassroots memorials for the 13 November attacks. These archival documents have been studied and coded, adding a quantitative dimension to the qualitative material of our study. ${ }^{3}$

These diverse data reveal that, even if migrants have mostly remained uninvestigated so far, they were definitely part of the memorialization process that took place in the immediate aftermath of the Paris attacks. In doing so, they participated fully in the overall post-attacks consensus, and relied on the local level, the one of Paris as their city, to identify with the event. However, as the time from the event passes on, the migrants' situation regarding the commemoration of 13 November appears to be problematic, particularly in the case of those originating from North Africa and Muslim countries. The construction of a shared collective memory through the planned permanent memorial museum will have to take care of this dimension in order to be inclusive and not to add yet another dimension of exclusion to the current public memory of terrorist attacks in France.

\section{Local dynamics, inclusiveness and migrants' participation in the grassroots memorials}

At the time of the attacks, the $11^{\text {th }}$ arrondissement was populated by almost 150000 inhabitants. It has been a place of immigration since the 1960s, mostly of people coming from North Africa. Since the beginning of the $21^{\text {st }}$ century, however, new inhabitants, from French and wealthy backgrounds, have been settling there. The 11th arrondissement is considered as one of the few areas of genuine and balanced social diversity that still exist in the French capital. 19\% of its population are migrants coming from a diversity of origins (INSEE 2017). During the fieldwork conducted at the grassroots memorials in the Bataclan neighbourhood, we had many encounters with migrants passing by, stopping for a few minutes or more, on rare occasions leaving a picture or a piece of paper with a handwritten message on the site. In most cases, they expressed themselves as being from abroad and living here, in Paris. Several messages were phrased as referring to groups of migrants, such as 'the Paris Sri Lankan People', 'the Tamil community', or 'the Kabyle people in Paris'. In several documents, the message even contains the word 'here' as in this example, 'That our children live in peace here and everywhere else', written in Spanish and French (translated by the authors).

The materials collected by the Paris Archives enable us to move beyond these idiosyncratic remarks to draw a more systematic picture. About 7700 paper documents were collected on the Parisian sites of the attacks, from 8 December 2015 to 1 March

\footnotetext{
${ }^{3}$ These three groups of data have been collected in the framework of the REAT research cluster, supported by the CNRS (https://reat.hypotheses.org).
} 
2016. They are now available online ${ }^{4}$. They enable us to produce some statistics about the content of the post-November attacks' memorialization. It turns out then that $6,4 \%$ of the messages left at these grassroots memorials refer to a foreign country or city and that 32 different languages other than French were used in them. Most frequently occurs English, in $20 \%$ of the messages, while all the other languages represent between 1,6\%, for Italian (the second most frequent after English), and 0,4\%, for Chinese. However, it is difficult to distinguish among these messages between those coming from migrants versus tourists. The overrepresentation of documents in English and of people quoting the USA or European countries may signify than tourists were more numerous than migrants in this process. Paris is indeed the most touristic city in the world.

Whether migrants or tourists, what these foreigners expressed in their messages left at the grassroots memorials in Paris is most often a sense of solidarity without specific identification with the victims. They speak on behalf of their country to express their support for Paris or, more often, France. For instance: 'USA stands with Paris', 'Turkey are in solidarity with the people of France' or 'Russia is with France'. Messages addressed to France, in particular, systematically follow this pattern - 'we are with you', meanwhile messages expressing a sense of direct identification with the victims - we are you - are almost always formulated at the local level of the city of Paris (emphasis added). The formula 'Je suis Paris' (I am Paris), inspired by the famous 'I am Charlie', that emerged and quickly gained international currency after the Charlie Hebdo attack in Paris on 7 January 2015, can be found in 4,8\% of the messages collected by the Paris Archives on the sites of the November attacks. Only $0,3 \%$ of them contain something like 'I am France / French'. This result is perfectly congruent with what was already observed in similar documents, namely those taken from the grassroots memorials that took were established in Madrid after the train bombings on 11 March 2004, collected through the 'Archivo del Duelo' research project (Sánchez-Carretero 2011). The anthropologist Cristina Sánchez-Carretero, who leads this project, remarks indeed:

While many examples of complete identification with Madrid or the train are found in the materials of the project, there are no similar examples with respect to Spain. For instance, messages saying 'Belgians are also Madridians' or 'we are all Madridians' were frequently found at the stations. At the same time, there is not evidence of even a single similar message stating that 'We are all Spain' or 'Ecuador is Spain'. (...) The level of the nation- state is employed to express solidarity among countries or to express shared sentiments, but it is not used to express total identification (Sánchez-Carretero 2019, p.82).

This recurrent observation refers to the fact that, except in the case of people with dual nationality, identification with a nation is exclusive, while identification with a city can be inclusive: modern cities, especially metropolises like Madrid or Paris, are, by nature, places of social mixing, open to all, cosmopolitan (Simmel 1950). Thus, being the inhabitant of a city is not the same as being member of a nation, and so the two do not come into conflict. Thus it is possible to say, 'the Turks are Paris' or 'I am Algerian, but I am also Paris'. However, declaring that 'the Turks, or the Algerians, are also French', or 'I am Algerian, but I am also French' - except, once again, in the

\footnotetext{
${ }^{4}$ http://archives.paris.fr/r/137/hommages-aux-victimes-des-attentats-de-2015/
} 
specific case of people with dual nationality - would strike many people as a logical contradiction (Truc 2018, p.151). It is worth noting that the messages left at the grassroots memorials by people from the overseas French territories (DOM-TOM) follow exactly the same pattern. Even if the Réunion island (or the Guadeloupe, but less cited) is indeed French territory and their inhabitants have French nationality, one can find in the messages left in front of the Bataclan sentences like or 'La Réunion is with you' or 'La Réunion is Paris' ${ }^{, 5}$. Such messages often appear next to the historic flag of the island along with the French flag, exactly as if their inhabitants were foreigners to the country attacked by the terrorists, like migrants or tourists.

Therefore, here is precisely what can allow us to identify messages specifically left by migrants within the grassroots memorials among all the foreigner's messages. Contrary to the tourists who do not live in Paris and therefore express their support to the victims as a solidarity of their country with France, the migrants settled in Paris, whether for days or years, express a direct identification with the victims at the local level of the city, building then an inclusive relation to the events. This direct identification is sometimes expressed in long messages, taking the shape of a personal narrative, as in the case, for instance, of this Chilean person, who tells his own migrant trajectory to explain why, although a foreigner, he is so sensitive to what is happening to his adopted city (translated from Spanish by authors):

To the French people, to Paris, I am writing in my native language as I did not learn yet to do it in French, hoping that some of you will understand what I am saying here. The first time I discover Paris was a long time ago. It was not for tourism. I left my country because I didn't have the right to live there with my ideas and convictions. I knew very closely the cruelty and arrogance of people pretending to say what is the true and the best for our country, Chile. Today, so many years later, I am overwhelmed to be here, knowing what is happening, without being able to do anything else than writing this $(\ldots)^{6}$.

But messages of this kind require narrative and linguistic skills, as well as a social disposition, to publicly expose one's life; not all migrants have such skills. Most of the messages of migrants expressing a sense of identification with the victims at the level of Paris are much shorter, using symbols, like flags, the Eiffel Tower and the 'Pray for Paris' logo, as well as ready-made formulas such as 'I am Paris'. In this way, some of them could also have been written by tourists. These are generally adapted to provide evidence of the migrant's origin - for instance, in the case of migrants from Algeria: 'Alger is Paris' or 'The Kabylia is Paris' [Fig.1].

\footnotetext{
${ }^{5}$ See for example, in the Paris Archives, documents 3904 W71-107 to 114.

${ }^{6}$ Paris Archives, document 3910W8-8
} 


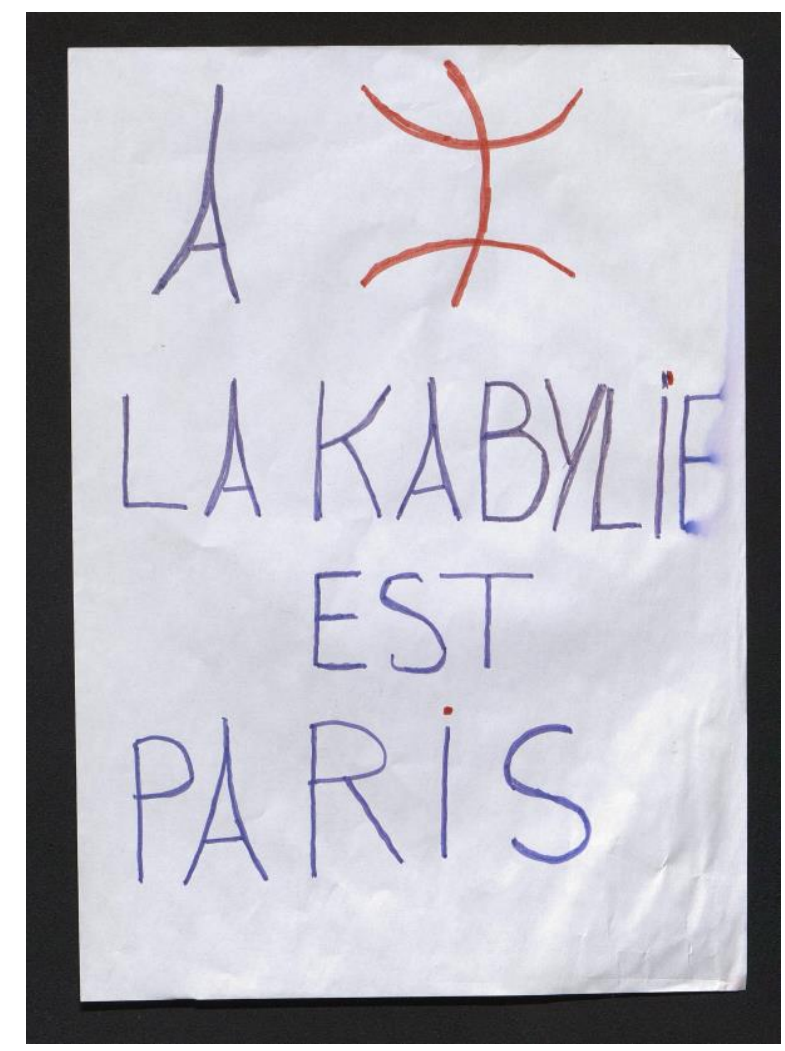

Fig.1 'Kabylia is Paris' (C) Paris Archives, document 3907W1-109

After the 11 March 2004 attacks in Madrid, messages written by migrants were mainly from countries of South America - Ecuador, Peru, Colombia, Argentina, etc. (Sánchez-Carretero 2011). Given the history of migration in France, it is not very surprising to note that in the case of the post-13 November grassroots memorials in Paris, countries of Africa, and more precisely former French colonies of North Africa prevail - particularly Algeria, but also Morocco and Tunisia. It must also be taken into account that the perpetrators of the November attacks were from families originating from these countries and that these Islamist attacks, consequently, were particularly difficult to live with for French citizens born in these same countries and of Muslim faith or culture (see Geisser et al. 2017; Beaud 2018, cpt.10).

Another group of people who can be identified among the migrants who left messages at the grassroots memorials, although a small minority, are refugees from Syria. The war in Syria and the 'refugee crisis' appears as one of the relevant geopolitical contexts of the 13 November attacks. Some 30 messages mention Syria, and several of them in particular were left on the different sites of the attacks in the name of the 'Free Syrians of France', along with Syrian flags [Fig.2]. The presence of these Syrian messages in the grassroots memorials can be interpreted as a means to raise awareness and solidarity with the Syrian cause among French people. One of these messages says for instance: 'Parisians, stay on your feet! The Syrians of France are with you. The blood flowing is the same in Syria and in Paris'. The Syrians are not the only ones to establish such links between the Paris situation and that of other cities or countries outside the Western world struck by terrorism. Some Kurds, for example, left this message at the Bataclan: 'Yesterday Kobane, today Paris. We are all Kurds, we are all 
Paris ${ }^{7}$. Here, migrants appear as a key factor in the transnationalization of the postNovember grassroots memorials in Paris.

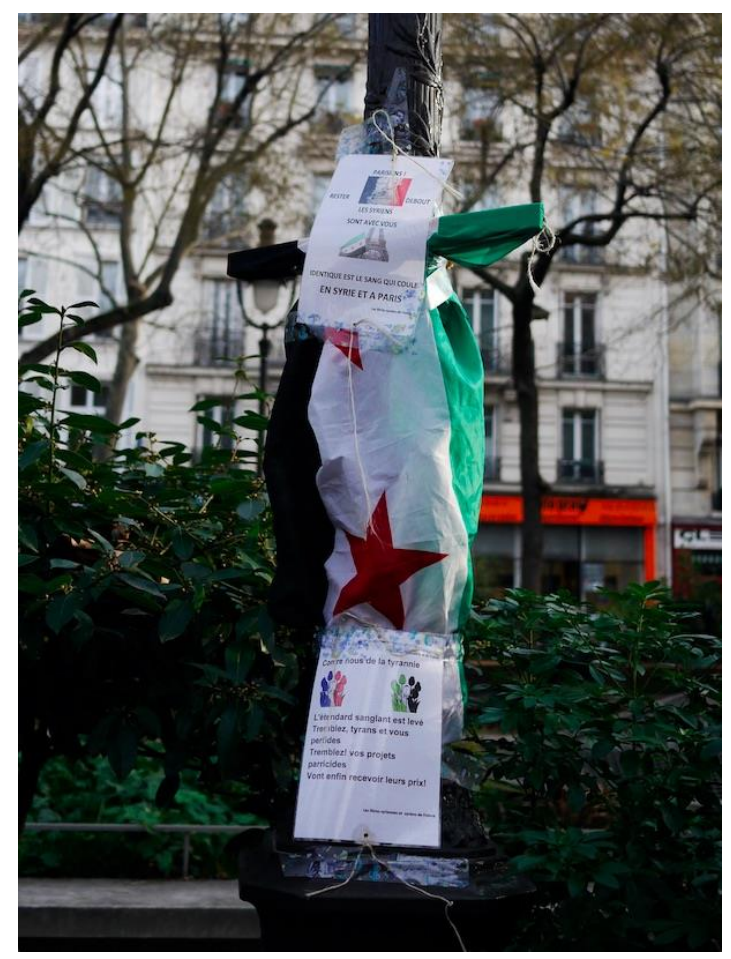

Fig.2: Messages left by the 'Free Syrians of France' in front of the Bataclan, 11 January 2016 ㅇ Gérôme Truc

This observation is consistent with the transnational turn taken by memory studies in the recent years (e.g. Assmann 2014). The imbrication between local feelings of belonging and global identification with extra-national groups confirms the importance of the 'glocal' in this transnationalization of memory (Erll and Rigney 2018). Since migrants took active part in the immediate memorialization which followed 13 November 2015, it is now important to take a closer look at the kind of narratives they referred to when visiting the sites of the attacks. Did migrant participation in grassroots memorialization contribute to the construction of cosmopolitan memory that is so often called for (Levy and Sznaider 2010) or did it illustrate the multidirectional nature of any evocation of the past (Rothberg 2009)? In other words, on whose 'travelling memories' (Erll 2014) did this transnationalization dynamic rely?

\section{Migrants' role in the transnationalization of grassroots memorials}

On 13 November 2015, almost 20\% of the victims were foreigners, this proportion would be even higher when including those who were both French and foreign nationals, but who are more difficult to identify as such in public data. This proportion results of course from the status of Paris as cosmopolitan metropolis. It explains that some of the first flags, flowers and messages to be left on the sites came from other

\footnotetext{
${ }^{7}$ Paris Archives, 3904W43-15.
} 
countries, from Portugal to Tunisia, as occurred previously in London after the bombings on 7 July 2005 (Truc 2018). From the start, the (bi)nationality of the victims and some of their close friends and relatives, staged the memorial as a transnational symbolic space. But beyond this first dimension, the transnationalization of the grassroots memorials also relied on the frequent inclusion of other terrorist attacks in the scope of the events to be mourned and memorialized on these sites. In December 2015, it was someone from Turkey who attached a message to the metal fence in front of the Bataclan, paying homage to the victims of the attack in Ankara on 10 October 2015. Again in January 2016, a man who identified himself as coming from Africa, pasted a short but clear message on a pre-existing pink poster speaking of love, 'I am Ouagadougou! with all my heart' [Fig.3], the Burkina Faso capital having just been hit by a terrorist attack. ${ }^{9}$

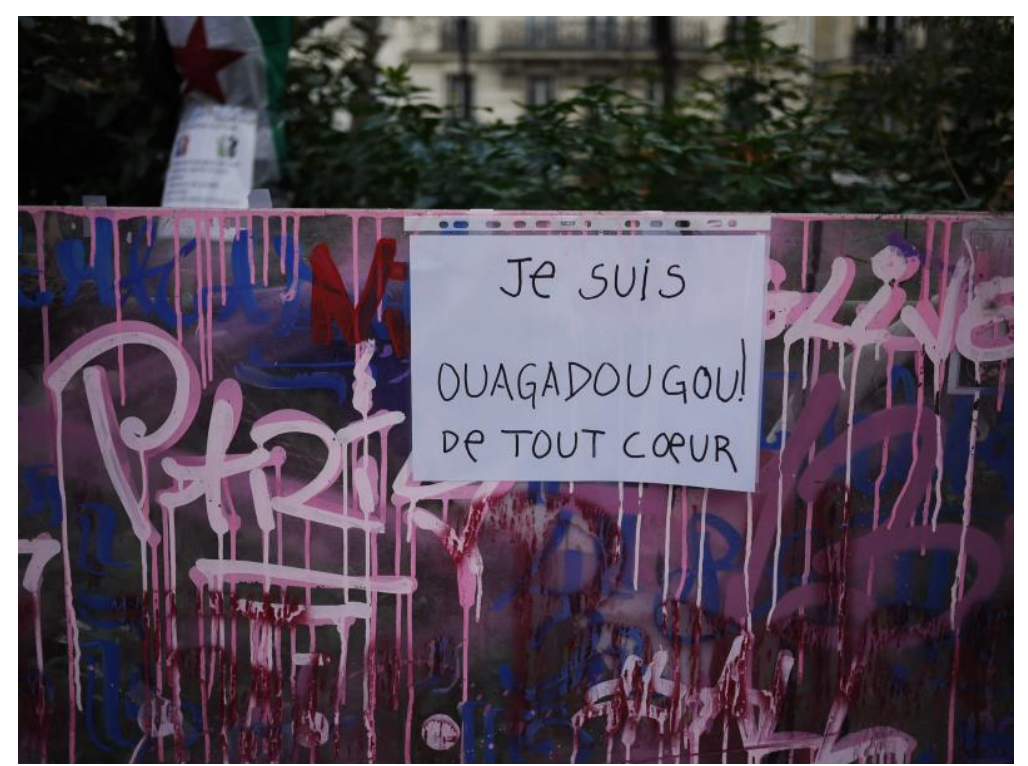

Fig.3: 'I am Ouagadougou! with all my heart'. Bataclan, Paris, 18 January 2016 (c) Gérôme Truc

Even more than the Bataclan site, it was the Place de la République where the transnationalization of the memory of the Paris attacks was most visible. Unfortunately, the materials collected by the Paris Archives in the grassroots memorials are of no help to highlight this since they include nothing from this site. This requires some explanation. Immediately after the Charlie Hebdo attack in January 2015, people spontaneously gathered around the Place de la République due to a combination of three factors. Firstly, it is one of the most important plazas in Paris, with a strong symbolic significance and a long story of public gatherings for celebrations and mass demonstration around its central monument - an allegoric

\footnotetext{
${ }^{8}$ On 10 October 2015, an attack in Ankara left 102 people dead and more than 500 wounded. A double explosion targeted a pacifist demonstration organized by left-wing forces. This occurred in a context of political tensions in Turkey.

${ }^{9}$ On the evening of 15 January 2016, a bar, a restaurant and a hotel in Ouagadougou, the capital of Burkina Faso, all primarily frequented by foreigners, were attacked by members of Al-Qaeda in the Islamic Maghreb.
} 
representation of the French Republic. Secondly, it is very close to the scene of the Charlie Hebdo attack, just a few blocks away; and thirdly, it had just been renovated and declared a pedestrian area at the time of the attack. Thus the most important grassroots memorials in Paris for the victims of the January 2015 attacks took shape there, and the Place de la République and its central monument internationally became the iconic place of memory for these attacks, even if no bullets were fired and nobody was killed right there. A few weeks after the attacks, when the city authorities started to remove tributes and clean the place, people protested. A group that baptized itself ' 17 never again' (in reference to the number of dead), emerged through social media organization, notably Facebook, to take charge of the maintenance of the memorials and take care of the tributes in memory of the victims (Truc and Bazin 2019). Thanks to their action as 'guardians of memory', the grassroots memorials stayed on the Place de la République throughout the summer of 2015 and were still there when the 13 November attack took place. After these new attacks, people went to the sites to pay tribute to the victims, as well as coming back to the Place de la République, to revitalize the grassroots memorials there. When the Paris Archives started to collect the content of the informal memorials on each site of the attacks (Bataclan and café terraces), they decided to leave the Place de la République aside to avoid any conflict with the ' 17 never again' group who, meanwhile, has come to act as custodian and quasi-owner of the grassroots memorials there (Truc and Bazin 2019). That is why researchers can in this case only rely on site observations, such as the following one we made in June 2016.

On 12 June 2016, a shooting took place in a popular gay nightclub in Orlando, Florida. ${ }^{10}$ Immediately, the grassroots memorial on the Place de la République echoed this new massacre. A gathering was held in tribute to the Florida victims, and new drawings and messages were left on the base of the statue. One young couple left a paper banner made that read 'The more you kill us, the more we will love each other'. The man, aged 26, and the woman, aged 23, were both philosophy students and had arrived in Paris from Portugal in September 2015. She was Portuguese and he was Belgian-Portuguese; both lived in the $18^{\text {th }}$ arrondissement at the time. They reported being particularly sensitive to issues around LGBT rights. That night they had come in response to the attack in Orlando and brought a banner [The more you will kill us, the more we will love each other], which they proceeded to hang with great care. The man wanted it to be displayed next to a Franco-Belgian tribute already left there in honour of the victims of the attacks that occurred in Brussels in March 2016, as though this location was an echo of his own national belonging. This was the first time that either of them had come to this site to participate in grassroots memorialization efforts after a terrorist attack. For the Brussels attacks, the young man said he had been 'too involved'; he 'called people' and 'didn't even think' of coming here. For the Paris attacks in November 2015, however, they 'had just arrived' in the capital. The symbolic meaning of their tribute to the victims was hence linked simultaneously to Orlando, Brussels and Paris.

\footnotetext{
${ }^{10}$ During the night of 12 June 2016, the day of Gay Pride, a man opened fire in a crowded nightclub in Orlando, Florida, popular with the LGBT community. 50 people were killed; Islamic State later claimed responsibility for the attack.
} 
The scholarly literature on the memorialization of terror attacks has stressed the cosmopolitan dimension without always identifying the concrete actors and vectors which make this transnationalization possible (Brown and Hoskins 2010; Milosevic 2017). Through these examples, outcomes of an in-depth ethnographic fieldwork process on the sites of grassroots memorials, the migrants appear as important actors in this transnationalization of solidarity and immediate commemoration after the attacks. As mentioned earlier, both migrants and tourists participated in this transnational memorialization dynamic, yet their responses differ. When tourists contributed to the informal memorials at the sites, it was generally a ready-made, individual and anonymous message, such as 'Pray for Paris'. When migrants left messages, on the contrary, they were more often in the form of a type of manifesto, collective and signed.

Moreover, in recent years, some scholars have rightly denounced the fact that this cosmopolitan solidarity only manifests itself when terror strikes cities in the Western world (Brassett 2008, 2010; Bond 2015; Heath-Kelly 2016). For example, Jouan (2017) comments critically on the difference in reactions following the attacks in Beirut on 12 November and in Paris on 13 November 2015, although Islamic State claimed responsibility for both. During our fieldwork, however, some migrants took advantage of the grassroots memorials to move beyond this North-South divide and claim visibility and solidarity for victims of terrorism in non-western countries in the global South. On 16 July 2016, a minute of silence was organized around the grassroots memorials on the Place de la République to mourn the victims of the massive attack which had taken place two days before, on Bastille Day, in Nice, a touristic city in the South of France. Once the ceremony was over, a large group of 50 men, visibly migrants from the Indian subcontinent, circled the main side of the memorial. After a few minutes, they displayed two large banners saying 'Bangladesh Buddhist Association, Paris France' and 'No place for terrorism in Bangladesh'. Jack Santino (2011) highlights the tension between apolitical commemoration and political activism, which lays at the very core of grassroots memorials. In the present case, migrants as a largely invisible and under-researched group of social actors turn out to participate as much as anyone in this social dynamic of informal memorialization. In fact, they even appear as major actors of the commemorative processes taking place at the grassroots memorials following the 2015 terrorist attacks in Paris.

\section{Commemoration, monuments and exclusion of the migrants}

The grassroots memorials discussed above were eventually doomed to disappear. The collection of the artefacts and documents that make up these informal memorials by the Paris Archives is unprecedented in France ${ }^{11}$, but the social uses of this heritage are yet to be explored. In any case, we can already see how the heritagization of these artefacts makes it impossible to distinguish between a 'pre-memorial era' (Simpson and Corbridge 2006) and a subsequent era of 'memorial mania' (Doss 2010). The

\footnotetext{
${ }^{11}$ Although such archival collection was unprecedented in France, this is not true for the set up of grassroots memorials or collective gatherings after terror attacks, which were observed in Paris as early as the $19^{\text {th }}$ century (Salomé 2010) and which have occurred more regularly since the $20^{\text {th }}$ century (Salomé 2015).
} 
immediate responses to the attacks on the one hand, and the commemoration of the events on the other, form a continuum (Truc 2017; Gensburger 2019) - stages in the ongoing process of memorialization that begins in the very first hours after the attacks and demonstrate the 'restlessness of events' (Wagner-Pacifici 2010).

This cyclical temporal framing, the time map, as Eviatar Zerubavel (2003) puts it, is associated with a memorial topography. At the time of writing, four years after the terrorist attacks, several sites in the Parisian public space still bear witness to their memory. In November 2016, for the first anniversary of the events, the Paris City Council and the French government made the decision to have the memorial topography reflect the cartography of the attacks. Commemorative plaques were inaugurated in each of the sites affected (cafés, concert hall and football stadium ${ }^{12}$ ). Each year on 13 November, the families of survivors and victims, individually or as part of victims' associations, return to these sites one after the other. These ceremonies are attended by the Mayor of Paris, Anne Hildago, and a state representative, the French President, François Hollande in 2016, Emmanuel Macron in 2017, and the Prime Minister, Edouard Philippe in 2018. They each lay an official wreath in turn, but none speaks; the ceremonies are completely silent. There is only the reading of the names of the dead, a now global ritual (Laqueur 2016), to break the silence. This litany, alternating feminine and masculine voices, was pre-recorded for the first anniversary and has been replayed every year since. Both before and after the reading of the names and the one minute of silence that follows, members of the audience are generally engaged in intense discussion. Their comments are political, for example, critically reflecting on the fact that the president and other ministers remain silent. Ethnographic observation of these ceremonies clearly demonstrates that there is no consensus around the meaning of the attacks (Who is to blame for these attacks? Were they parts of a 'war' or not? A consequence of French foreign policy? Or of some laxity in immigration policy?). There is also little agreement on how and which memories should be preserved (Are commemorative plaques enough? Do we need something else, like a monument or a memorial museum? If so, where should it be set up? Should the Bataclan indeed be the main lieu de mémoire for the 13 November attacks?). Behind the commemorative consensus that characterizes much of the grassroots memorials, and beyond the questions around resilience that run through French society as a whole, the multiplicity of meanings given to the attacks and their memory are clearly visible here. They also demonstrate the symbolic weakness of the contemporary political representation on this issue (Boussaguet and Faucher 2017). Within this audience, balancing between consensus and conflict in front of the commemorative plaques during commemorations, migrants occupy a singular position.

A one-week full time fieldwork process was conducted in 2016, 2017 and 2018 respectively in front of the commemorative plaques and former sites of grassroots memorials during the commemorative period. ${ }^{13}$ This research material enables us to

\footnotetext{
${ }^{12}$ The night of 13 November 2015 started with the attack of the Stade de France in Saint-Denis, in the suburbs of Paris.

${ }^{13}$ These observations were conducted with Sylvain Antichan, Delphine Griveaud and Solveig Hennebert.
} 
investigate the migrants' relationship to the permanent memorials in memory of 13 November. It appears that the distance to the events on the one hand, and the institutionalization of collective remembering, from grassroots memorials to permanent memory markers, on the other, have created tensions within the migrants' position, particularly in the case of people coming from North Africa and Muslim countries.

The commemoration ceremonies in front of the plaques take place on a consensual basis and refer mainly to a national scale, embodied by the presence of either the French President or the Prime Minister. The audience adopts a ritualistic mourning behaviour and for this occasion, the grassroots memorials come back to life. People leave messages of 'peace', 'love' and 'togetherness'. Some flags appear again at the sites, but this time they are only French ones. However, once the ceremony ends or if the observer moves a few meters away, the scene changes radically and the staged impression of national unity fades drastically. One can observe, for instance, small groups of people criticizing government policy from multiple perspectives. Some regret that the attacks did not lead to changes in terms of foreign affairs; they call for a stop to French military interventions in Africa and the Middle East. Others adopt a domestic affairs perspective and would have liked the terror attacks to create more collective awareness about ethnic discrimination in France. At the opposite end of the scale, some prefer the French State to be more repressive of Muslim religious extremism in France.

Beyond the ritualistic expression of pain, sadness and concern, discussions between people who did not know each other before the commemoration ceremony are very uncommon. On 15 November 2016, the remembrance cycle of the first anniversary was still ongoing. We stood in front of the commemorative plaque recording the names of the dead at the Bataclan concert hall. When we arrived, a man called out to us: 'Please can you hold a minute of silence with me'. During the ensuing one minute, he silently read the names and concluded with 'shall they rest in peace'. The discussion began while he lighted some candles. From the outset, he declared that he was more empathic and in shock than the 'native-born French people' and went on to spontaneously identify himself as 'Arabic' ('it shows on my face right?') and a Muslim. He told us about his personal history and the role played by the wake of terrorism in Algeria that motivated his family's migration to France. He concluded his speech on a very angry tone, one that we rarely witnessed in the vicinity of the memorials and commemorative plaques: 'these terrorists they should go and be fucked by horses'.

Everything took place as if the presence of this man was socially necessary but at the same time in tension, between social pressure and illegitimacy, reflecting the unmanageable position of Muslims in France, following the new wave of Islamic terrorism which has started in 2015 (Geisser and al. 2017). As it happens, and without any deliberate choice on our part, a large part of the people we managed to speak with on the memorial sites during the commemorations, were migrants from North Africa. 
Some of them even reached out to us and other members of our research group spontaneously as if they wanted their presence to be noted and acknowledged.

Moreover, most of the open conflicts and occasionally vicious arguments we witnessed during the annual commemorations involved migrant people, usually arguing with each other. On 13 November 2016, around 7pm on the Place de la République, in front of the central statue, a violent dispute started. For several hours, a man wrapped in a huge French flag had been selling French flags and candles for a handful of euros, a few meters away from the statue. He had a strong North African accent and his face was typical of the labour migrants who came to France in the 1960-70s. A black man, around 50 years old and very neatly dressed, came closer to the statue and left a note about peace. On his way back, he stopped in front of the man with the flags and aggressively shouted at him, in French, with a clear African accent: 'you should be ashamed of yourself! Making money out of pain and grief. Go back home! Please just go back home!' 14 , in a mix of anger and pity. If the expression 'go back home' could be understood literally, it was not in this way that the people witnessing the scene made sense of it and neither did the man with the flags. He replied vividly, in French and also with a strong accent, 'This is my home, France is my home sir!'. The argument went on for a few more minutes, the first one repeating 'But go home! Leave, please leave. You make me ashamed' and the other replying 'I am home as much as you are'.

\footnotetext{
${ }^{14}$ In the French language, two different pronouns exist for the English 'you'. It may be noted that the black man used the familiar 'tu' when addressing the migrant, which is usually reserved for people who know each other quite closely. The migrant equally responded by using 'tu' .
} 


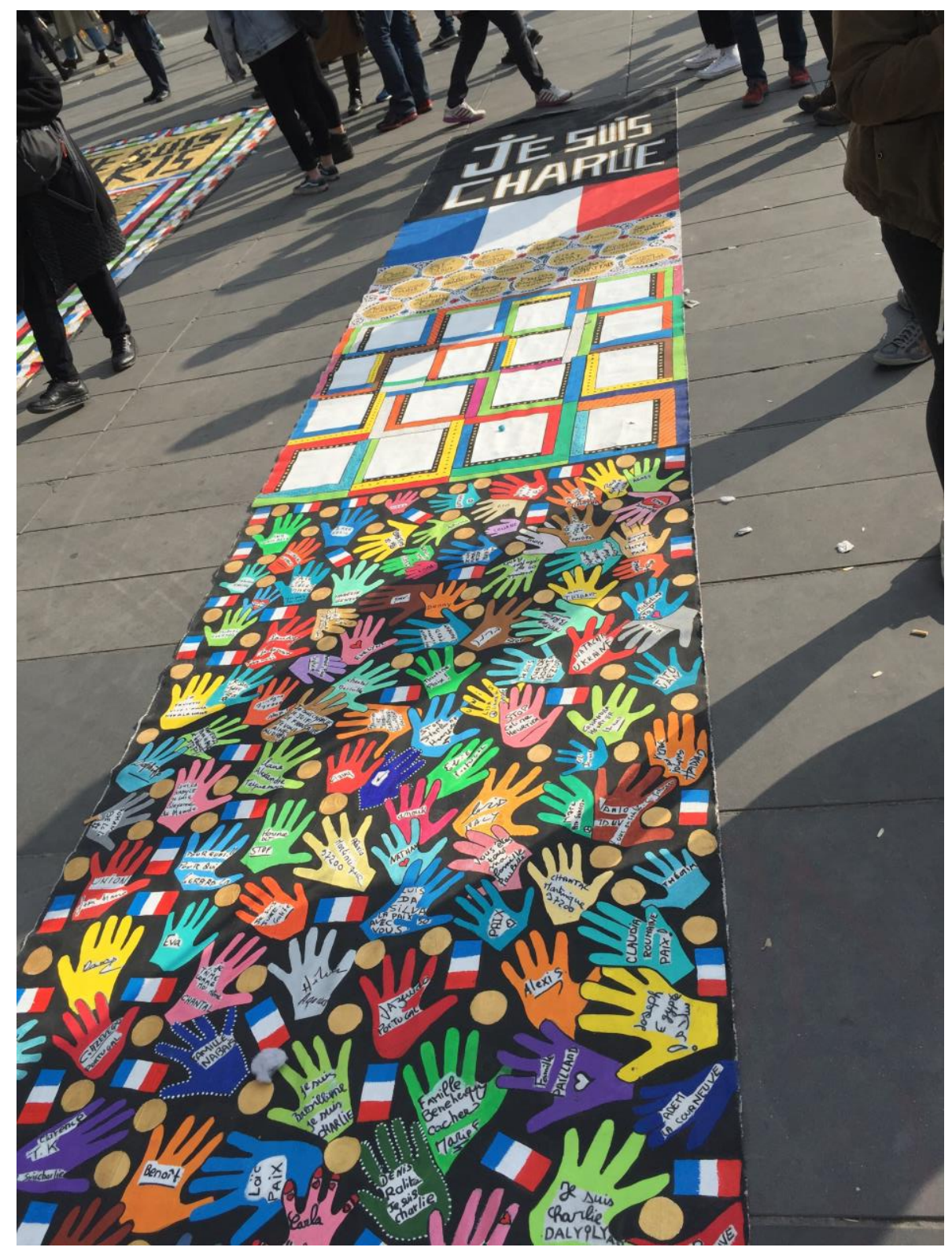

Fig.4. The recurring banner $\odot$ Sarah Gensburger

Two years later, on 13 November 2018, another public dispute took place in front of the statue on the Place de la République, the main site of the former grassroots memorials. During each commemoration since 2015, we had noticed a 20 meters long banner, demonstratively brought back each time by its creator [Fig.4]. The concept underpinning this commemorative piece involves the collection of handprints; people were asked to print their hand and colour it in one of the thousands of squares designed on the long piece of fabric and write a message inside the print. This banner is possibly the most important participatory commemorative memorial to exist so far in relation to the Paris attacks. This year (2019) we decided to contribute to it ourselves. A young man, around 25 years, was signing it at the same time, writing 'Kabylia' in his print, referring to a region in northern Algeria. That was not surprising. After more than three years of fieldwork, we had already noticed how many people in the $11^{\text {th }}$ arrondissement, and in Paris more generally, had connections 
with Kabylia ${ }^{15}$. Kabyle flags were very frequent on the grassroots memorials. On 11 January 2015, during the enormous demonstration that had followed the Charlie Hebdo attacks of 7 January ${ }^{16}$, we had already been struck by the number of these blue and yellow flags among the crowds that had visited the neighbourhood, which ten months later would be known as the 'Bataclan neighbourhood'.

While we were hence little surprised at the man's inscription, a woman in her fifties almost jumped on the young man, challenging him, 'Why did you write that?! I created this piece of fabric for people to share a common humanity and not for you to bring back here the causes of civil wars and conflicts that I left behind me in Algeria'. The woman who had initiated this participatory banner turned out to be a migrant from Algeria who had been married to a man from Kabylia and felt that her husband's family resented her non-kabyle origin. Quickly approximately 30 people gathered around the woman and the young man who started to speak alternatively in Kabyle's vernacular language and Arabic. Most of the people seemed to understand the verbal exchanges. Here again, migrant people from North Africa seemed to be defining their place in and belonging to French society, through the participation in the commemoration and their relationship to the memorials. Arguing that we and three other people close to us were unable to understand the conversation in Arabic, we asked the woman and the young man to skip to French: 'It is not fair that we cannot participate'. The woman turned to us and said, in French and in a friendly manner, 'You are right, I made this banner to include everyone'. The conversation then opened to other participants and quickly focused on the legitimacy for people from North Africa and of Muslim origin to take part in this commemoration on the one hand, and on the discrimination and racism they had to cope with since the event, on the other. At this point, the migrants' relationship to the commemorative monuments of 13 November appeared both inclusive and exclusive.

As a conclusion, we can say that if migrants have mostly remained neglected in the study of the societal response to the Paris terrorist attacks, they were definitely part of the memorialization process that took place in the immediate aftermath. In doing so, they participated fully in the overall dynamic of remembering and commemorating, and relied on the local level, Paris as their city, to identify with the event. However, when we move away from the event, the migrants' situation regarding the commemoration of 13 November appears to be problematic, especially in the case of those originating from North Africa and Muslim countries, moving from inclusiveness to exclusion. In the Paris case, paying attention to migrants as actors of commemoration is crucial and urgent since, in September 2018, the French president announced the creation of a national memorial museum for victims of terrorism, which will, with no doubt, give special attention to the popular expression of grief at the grassroots memorials (Gensburger 2019). Giving voice to the migrants' practices at

\footnotetext{
${ }^{15}$ Kabylia is a northern region of Algeria whose people have been claiming autonomy first from the French state and, after 1962, from the Algerian one.

${ }^{16}$ On 11 January 2015, 2 million people demonstrated in Paris, in protest against the attacks that had occurred the week before. Several commentators described this march as 'republican'.
} 
these memorials must definitely be part of a larger ongoing reflection on the best way to preserve the past as a way to build the future.

These empirical conclusions highlight furthermore the ongoing theoretical reflections on the transnational dimension of contemporary memory dynamics in Paris. If the transnational scale is central to the current literature in the field of memory studies, so far, few works have managed to resolve the 'tension between the production of remembrance through transnational processes and its grounding in concrete locations', as Jenny Wüstenberg (2019, p.1) has rightly acknowledged in a recent journal special issue on Locating transnational memory. One of the ways to resolve this tension has been to pay attention to travelling memory (Erll 2011) and to the circulation of memory actors who work at obtaining official recognition of past offenses and commemoration of difficult pasts (Hasunuma and McCarthy 2019). However, this chapter suggests that the transnationalization of memory can also rely on the grounding of migrants in concrete locations who, far from being memory entrepreneurs, invest monuments, memorials and sites of commemoration with contemporary issues which have no real links with the public evocation of the past. A new question arises then: how have monuments, memorials and commemoration sites become a relevant place for migrants to speak publicly? This chapter calls for not only studying the transnationalization of memory, but also, symmetrically, the memorialization of the transnational (Dybris McQuaid and Gensburger 2019).

\section{References}

Allen, M., and Brown, S. D. 2016. Memorial meshwork: The making of the commemorative space of the Hyde Park 7/7 Memorial. Organization, 23(1), 1028.

Antichan, S., Griveaud, D. \& Gensburger, S. 2017. La mémoire en ses lieux. Essai de topographie de la première commémoration du 13 novembre 2015 à Paris. Mémoires en jeu, 4, 50-60.

Assmann, A. 2014. Transnational Memories. European Review, 22(4), 546-556.

Beaud, S. 2018. La France des Belhoumi : portraits de famille (1977-2017). Paris: La Découverte.

Ben A. A. 2000. Funerals, Politics and Memory in Modern France 1789-1996. Oxford: Oxford University Press.

Bond, L. 2015. Frames of Memory after 9/11. Culture, Criticism, Politics and Law. Basingstoke, UK: Palgrave Macmillan.

Boussaguet, L. and Faucher, F. 2017. The Politics of Symbols: Reflections on the French Government's Framing of the 2015 Terrorist Attacks. Parliamentary Affairs, 71 (1), 169-195.

Brassett, J. 2008. Cosmopolitanism vs. Terrorism? Discourses of Ethical Possibility Before and After 7/7. Millennium: Journal of International Studies, 36(2), 121147.

Brassett, J. 2010. Cosmopolitan Sentiments After 9-11: Trauma and the Politics of Vulnerability, Journal of Critical Globalisation Studies, 3, 12-29. 
Brown, S. D. and Hoskins, A. 2010. Terrorism in the new memory ecology: Mediating and remembering the 2005 London Bombings. Behavioral Sciences of Terrorism and Political Aggression, 2, 87-107.

Chulilla, J. L. 2005. Presencia de las comunidades inmigrantes en los Santuarios Populares del 11-M. In J. L. Chulilla and P. Azagra (Ed.), Espacios urbanos e immigracion en el Madrid del s. XXI (pp. 364-403). Madrid: La Casa Encendida.

Délano, A. and Nienass, B. 2014. Invisible Victims: Undocumented Migrants and the Aftermath of September 11. Politics \& Society, 42(3), 399-321.

Doss, E. 2008. The Emotional Life of Contemporary Public Memorials. Towards a theory of temporary memorials. Amsterdam: Amsterdam University Press.

Doss, E. 2010. Memorial Mania. Public feeling in America. Chicago and London: University of Chicago Press.

Døving, C. A. 2018. Homeland ritualised: an analysis of written messages placed at temporary memorials after the terrorist attacks on 22 July 2011 in Norway, Mortality, 23(3), 231-246.

Dybris McQuaid, S. and Gensburger, S. 2019. Administrations of memory: Transcending the nation and bringing back the state in memory studies. International Journal of Politics, Culture and Society, 32 (2), 125-143.

Edkins, J. 2011. Missing: Persons and Politics. Ithaca: Cornell University Press.

Elliott, A. 1999. The Mourning of John Lennon. Berkeley: University of California Press.

Erll, A. and Rigney, A. 2018. Cultural Memory Studies after the Transnational Turn. Memory Studies, 11(3), 272-273.

Erll, A. 2011. Travelling Memory. Parallax, 17(4), 4-18.

Fureix, E. 2009. La France des larmes: Deuils politiques à l'âge romantique (18141840). Paris: Champ Vallon.

Gensburger, S. 2019. Memory on my doorstep. Chronicles of the Bataclan Neighbourhood (Paris, 2015-2016). Leuven: Leuven University Press.

Gensburger, S. 2018. Beyond Trauma. Researching Memory on My Doorstep. In D. Drozdzewski and C. Birdsall (Eds.), Doing Memory Research: New Methods and Approaches (pp. 109-128). London: Palgrave.

Geisser, V., Marongiu-Perria, O. and Smaïl, K. 2017. Musulmans de France, la grande épreuve: face au terrorisme. Ivry-sur-Seine: Les Éditions de l'Atelier.

Guisan, C. 2009. Of September 11, Mourning and Cosmopolitan Politics. Constellations, 16, 563-578.

Hasunuma, L. and McCarthy, M. 2019. Creating a Collective Memory of the Comfort Women in the USA. International Journal of Politics, Culture and Society, 32(2), 145-162.

Heath-Kelly, C. 2016. Death Security: Memory and Mortality at the Bombsite. Manchester: Manchester University Press.

INSEE. 2017. Une mosä̈que sociale propre à Paris, Insee Analyses Ile-de-France, $\mathrm{n}^{\circ} 53$.

Jouan, M. 2017. Politique du deuil: entre reconnaissance et invisibilisation. Raison publique, 21(1), 113-152.

Kear, A. and Steinberg, D. L. (Eds.) 1999. Mourning Diana: nation, culture and the performance of grief. London: Routledge. 
Laqueur, T. 2016. The Work of the Dead. A Cultural History of Mortal Remains. Princeton: Princeton University Press.

Levy, D. and Sznaider, N. 2010. Human Rights and Memory, University Park: Penn State University Press.

Lödén, H. 2018. 'It s difficult to be a Norwegian': Minority voices in the memorial messages after the terror attacks in Norway 2011, Nordic Journal of Migration Research, 8(1), 56-64.

Magry, P., and Sánchez-Carretero, C. (Eds.). 2011. Grassroots Memorials: The Politics of Memorializing Traumatic Death. Oxford, UK: Berghahn Books.

Rothberg, M. 2009. Multidirectional Memory: Remembering the Holocaust in the Age of Decolonization. Stanford University Press.

Salomé, K. 2015. La France, scène du terrorisme international - 1982-2015. In E. Laurentin (Ed.), Comment en sommes-nous arrivés là ? Histoire d'une République fragile (pp. 171-176). Paris, Fayard.

Salomé, K. 2010. L'attentat de la rue Nicaise: l'émergence d'une violence inédite ?. La Revue d'histoire du XIXe siècle, 40 (1), 59-75.

Sánchez-Carretero, C. (Ed.). 2011. El Archivo del duelo : análisis de la respuesta ciudadana ante los atentados del 11 de marzo en Madrid. Madrid: CSIC.

Sánchez-Carretero, C. 2019. Emotions, Neighbors and Nation-State Identifications at the Grassroots Memorials of the Madrid Train Bombings. Ethnologie française, $173,77-88$.

Santino, J. 2006. Spontaneous shrines and the public memorialization of death. New York, NY: Palgrave-Macmillan.

Santino, J. 2011. Between Commemoration and Social Activism: Spontaneous Shrines, Grassroots Memorialization, and the Public Ritualesque in Derry. In P. Magry and C. Sánchez-Carretero (Eds.), Grassroots Memorials. The Politics of Memorializing Traumatic Death (pp. 97-107). New York, NY: Berghahn Books.

Simmel, G. 1950. The Metropolis and Mental Life. In K.H. Wolff (Ed., Tr.), The Sociology of Georg Simmel (pp. 409-424). New York and London: The Free Press.

Simpson, E. and Corbridge, S. 2006. The Geography of Things That May Become Memories: The 2001 Earthquake in Kachchh-Gujarat and the Politics of Rehabilitation in the Prememorial Era. Annals of the Association of American Geographers, 96(3), 566-585.

Tota, A. L. 2003. La città ferita. Memoria e commucazione pubblica della strage di Bologna, 2 agosto 1980. Bologna: Il Mulino.

Tota, A. L. 2004. Ethnographying Public Memory: The Commemorative Genre for the Victims of Terrorism in Italy. Qualitative Research 4(2), 131-159.

Tota, A. L. 2005. Terrorism and Collective Memories: comparing Bologna, Naples, Madrid 11 March. International Journal of Comparative Sociology, 46 (1-2), 5578.

Truc, G. 2011. Le politique aux marges de la commémoration: une ethnographie des cérémonies de commémoration officielle des attentats du 11 mars 2004 à Madrid. In M. Berger, D. Cefaï, C. Gayet-Viaud and J. Stavo-Debauge (Eds.), Du civil au politique: ethnographies du vivre- ensemble (pp. 205-227). Bruxelles: Peter Lang. 
Truc, G. 2012. Memory of places and places of memory: for a Halbwachsian socioethnography of collective memory. International Social Science Journal, 203204, 147-159.

Truc, G. 2017. Mémorialisations immédiates, Mémoires en jeu, 4, 47-49.

Truc, G. 2018. Shell Shocked: The Social Response to Terrorist Attacks. Cambridge: Polity Press.

Truc, G. and Bazin, M. 2019. Les gardiens de la mémoire : mobilisations et conflits d'appropriation autour de mémoriaux post-attentats à Madrid, Londres et Paris. Ethnologie française, 173, 63-75.

Wagner-Pacifici, R. 2010. Theorizing the Restlessness of Events. American Journal of Sociology, 115(5), 1351-1386.

Walter, T. (Ed.). 1999. The Mourning for Diana. Oxford/New York: Berg.

Walter, T. 2001. From cathedral to supermarket: Mourning, silence and solidarity. Sociological Review, 49(4), 494-511.

Wüstenberg, J. 2019. Locating Transnational Memory. International Journal of Politics, Culture and Society, https://doi.org/10.1007/s10767-019-09327-6

Yocom, M. R. 2006. We'll watch out for Liza and The kids: Spontaneous memorials and personal response at the pentagon, 2001. In J. Santino (Ed.), Spontaneous shrines and the public memorialization of death (pp. 57-97). New York, NY: Palgrave Macmillan.

Zerubavel, E. 2003. Time Maps. Collective Memory and the Social Shape of the Past. Chicago, IL: University of Chicago Press. 